\title{
Beyond formal R\&D: Taking advantage of other sources of innovation in low- and medium-technology industries $\equiv$
}

\author{
Lluís Santamaría $^{\mathrm{a}, *}$, María Jesús Nieto ${ }^{\mathrm{b}, 1}$, Andrés Barge-Gil $^{\mathrm{c}, 2}$ \\ a Departamento de Economía de la Empresa, Universidad Carlos III de Madrid, C/Madrid, 126-Getafe, 28903 Madrid, Spain \\ ' Sección de Organización de Empresas, Universidad Carlos III de Madrid, C/Madrid, 126-Getafe, 28903 Madrid, Spain \\ ' Instituto de Economía, Universidad Carlos III de Madrid, C/Madrid, 126-Getafe, 28903 Madrid, Spain
}

A R T I C L E I N F O

Article history:

Available online 21 November 2008

\section{Keywords:}

Low- and medium-technology industries

Technological activities

External sources

Innovation outputs

Market characteristics

\begin{abstract}
A B S T R A C T
This study deepens our knowledge of critical success factors in the innovation process of low- and mediumtechnology (LMT) industries. To accomplish this, it explores how the innovation process in LMT firms may depend on non-formal R\&D activities and the use of external sources. The empirical analysis is based on a representative panel of Spanish manufacturing firms. The results strongly support the view that nonR\&D activities such as design, the use of advanced machinery and training are crucial to understanding the innovation process of any firm. The study finds, however, that the impact of these activities is especially important in LMT industries, particularly for the achievement of product innovations. The empirical evidence also reveals the importance of external sources such as the use of consultants, the hiring of personnel, collaboration agreements and external R\&D, with the greatest differences between LMT and high-technology (HT) firms being observed in process innovations.
\end{abstract}

\section{Introduction}

An ability to develop and implement innovations is increasingly important for firms in all industries to survive in markets that are ever more global and competitive. Traditionally, however, there has been more interest in studying the innovative behavior of so-called high-tech (HT) industries than of low- and mediumtechnology (LMT) industries (Hirsch-Kreinsen et al., 2005). This interest appears disproportionate given that mature LMT industries still make up the largest part of the manufacturing industries in OECD countries and that their preponderance is falling at a very slow rate (Kaloudis et al., 2005). The lack of research interest in the innovative behavior of LMT firms may be explained by the pre-eminence of the linear model of innovation, the configuration of R\&D statistics, and misunderstanding the innovation process (Hirsch-Kreinsen et al., 2005, 2006).

The linear model of innovation emphasizes the scientific content of technological knowledge applied in firms. It focuses on formal R\&D as a source of innovation and neglects the vital role played by other activities and behaviors such as design, training or the use of

\footnotetext{
* Corresponding author. Tel.: +3491 6248643; fax: +34916249607. E-mail addresses: Isantama@emp.uc3m.es (L. Santamaría), mnieto@emp.uc3m.es (M.J. Nieto), abarge@eco.uc3m.es (A. Barge-Gil).

${ }^{1}$ Tel.: +34 91 6245826; fax: +34916245707.

2 Tel.: +34 91 6249302; fax: +34916249515
}

advanced machinery and tools. Innovation in LMT firms is not usually based on the latest scientific or technological knowledge, but often involves internally experimenting with and adapting technologies and learning that are not necessarily rooted in formal R\&D components. There is, though, no reason to believe that LMT firms are less likely to be able to face the challenge of innovation than R\&D-intensive firms (Bender and Laestadius, 2005).

The design of standard statistics in innovation has paid great attention to $R \& D$ processes and has made $R \& D$-related variables and R\&D departments the main, almost the only, locus of the innovation process. This has greatly limited research in LMT industries as many of the activities leading to innovation are not R\&D-based. As a result, although knowledge investments in LMT industries can be very profitable, this is not revealed by empirical studies that usually rely exclusively on R\&D activities as a measure of inputs (Bagchi-Sen, 2001; MacPherson and Ziolkowski, 2005). Given that firms in LMT industries can take great advantage of other innovative activities (Hansen and Serin, 1997), it is necessary to deepen our understanding of activities not based exclusively on formal R\&D.

Lastly, the innovation process is often misunderstood as something that is not embedded in the whole economic environment of firms. The behavior of LMT industries is an important indicator of the rate of investment in the economy in general. The role of LMT industries is undeniable as they are not only generators of innovation, but also key users of innovation generated in HT industries. In fact, LMT industries are often the best customers of HT industries and the levels of performance of LMT and HT industries are 
heavily interdependent (Robertson and Patel, 2007). This idea of exchanges of knowledge and the interconnection between industries and firms leads us to consider the relevance of external sources of innovation.

Previous considerations reveal the importance of discovering and analysing the innovative behavior of LMT firms. In addition to carrying out a theoretical exploration of the importance of different activities and sources of innovation, this article has two empirical objectives. First, it studies the impact of a wide range of innovative activities beyond formal R\&D on different innovation outputs such as product and process innovations and patents. Second, it analyses the potential effects of different sources of innovation beyond the boundaries of the firm on these same innovative outputs.

In this article, we advance our knowledge of the innovation behavior of LMT firms via a quantitative analysis of micro-data. This type of research has scarcely been performed concerning this issue. Although previous researchers have made an effort to study the determinants of innovation in LMT industries in greater detail, it is more common to find case studies (see for example, Pedersen, 2005; Schmierl and Köhler, 2005) and quantitative macroeconomic analyses (Kaloudis et al., 2005; Robertson and Patel, 2007).

To accomplish these tasks our empirical research is based on the Spanish Ministry of Industry's Spanish Business Strategies Survey (SBSS), a source of data that has been used by many other researchers to study aspects of innovation (Beneito, 2006; CuervoCazurra and Un, 2007; Huergo, 2006). The SBSS is rich in firm-level information, which makes it more useful than standard innovation databases that capture only a small portion of potential innovation determinants (de Jong and Vermeulen, 2006). In contrast to these databases, the SBSS does not limit its focus to innovative firms and firms' R\&D activities, but offers a more extensive picture. This characteristic allows us to go far beyond formal R\&D activities as a determinant of innovation in some aspects. First, it makes it possible to consider other activities influencing innovation, such as design, training and the use of advanced machines and tools. Second, it permits us to analyse several alternatives for internal R\&D activities, such as the use of technological consultants, recruitment of people, buying external R\&D, cooperation with different agents and formalization of $R \& D$ joint ventures. Moreover, it is possible to analyse the effects of the degree of competition in product markets, the accessibility of inputs in factor markets on firms' innovation outputs, and the characteristics of the markets in which firms operate.

Section 2 of the paper develops some arguments on the potential impact of innovation activities beyond formal R\&D and on the importance of sources of innovation beyond firms' boundaries. Section 3 contains descriptions of our data, variables and empirical models, and Section 4 presents our results. The final section includes our conclusions and describes some political and managerial implications.

\section{Theoretical framework}

\subsection{Beyond formal RED: other innovation activities}

Most previous studies have focused on the importance of R\&D activities as the determinant of innovation (Hirsch-Kreinsen et al., 2005). Innovation, however, is "the search for, and the discovery, experimentation, development, imitation and adoption of new products, new production processes and new organizational setups" (Dosi, 1988; p. 222). In other words, many activities that lead to innovation are not R\&D-based. As Rosenberg (1982) suggests, innovation performance is greatly influenced by the "grubby and pedestrian" activities of firms (e.g. design). Moreover, R\&D accounts for barely a quarter of the total expenses aimed at obtaining product innovations (Kleinknecht et al., 2002).
The consequences of this innovation research bias have been especially serious for our understanding of innovation determinants in LMT industries, owing to the specific characteristics of the innovation process in these industries. LMT innovation is not usually the result of the latest scientific or technological knowledge; it is more often based on transforming the general stock of knowledge into economically useful knowledge (Bender and Laestadius, 2005). The adoption and adaptation processes, therefore, are of fundamental importance. And as Metcalfe (1988) has suggested, the adaptation of technologies to particular circumstances involves internal experimentation, learning, appraisal and evaluation of technologies that may or may not have a formal R\&D component. In LMT industries, the main platform for innovation processes is not technological knowledge, but creativity and innovation-enabling capabilities, which are related to the abilities required to identify and assimilate the potentially relevant knowledge and translate it to fit the specific conditions of the firm (Bender and Laestadius, 2005). In line with this, Laestadius et al. (2005) propose a new system of innovation indicators that, along with the conventional measures of R\&D intensity, includes design, technological intensity (related to the use of machinery and equipment) and skill intensity (related to the qualifications of staff and ongoing training).

Design is a creative process that can be rational, innovative or artistic (Laestadius et al., 2005). Design refers to the stages of detailed development that are necessary to translate the first prototype into a successfully manufactured product (Marsili and Salter, 2006). The basic idea of design is to achieve a fit between two entities: form and context (Bender and Laestadius, 2005). Although some studies have shown that design activities can have a positive effect on innovation outputs (Marsili and Salter, 2006) and export performance (Sterlacchini, 1999), they have not indicated to what extent they may be essential in LMT industries. Some authors have noted, however, that LMT products usually compete on design, functionality and quality rather than just on price (Hansen and Serin, 1997).

Another activity driving innovation outputs is the use of advanced manufacturing technology. This reflects an interactive learning process that helps develop firms' competences (Sohal et al., 2006). The benefits gained as a consequence of this process come from several areas: coping with changes to products and to the volume of production; better allocating of staff; improved flexibility; enhanced organizational performance; and reduced production costs (Hofmann and Orr, 2005). Empirical analysis aimed at explaining innovation output, though, has not typically examined the importance of using advanced manufacturing technology. Pavitt's taxonomy (Pavitt, 1984) reveals that many LMT industries are supplier-dominated, implying that a lot of their innovation processes adapt externally acquired technology and make it function in a new environment (Hansen and Serin, 1997). All of which points to the use of advanced manufacturing technology being a critical factor in the innovation process of LMT firms.

The role of training is also inextricably linked to innovation performance (Warner, 1996). It is a key activity to bring staff knowledge up to date, thereby increasing the human capital of the firm and its absorptive capacity (Cohen and Levinthal, 1990). Training is especially important in LMT industries because many employees need to have knowledge of several disciplines, and therefore require hybrid qualifications that are not usually offered by the market (Schmierl and Köhler, 2005). ${ }^{3}$ There are, however, very few empirical studies

\footnotetext{
3 They cite the example of paper makers. Although paper makers do not rely on practical skills as much as in the past, they now need more technical skills and hybrid qualifications (of mechanics, electronics, hydraulics, etc.) to run paper machines. In
} 
that research the impact of ongoing training on innovation outputs. A notable exception is the work by Freel (2005), which concludes that the most innovative firms train staff more. ${ }^{4}$

\subsection{Beyond firms' boundaries: external sources of innovation}

As innovation occurs primarily through new combinations of resources, ideas, and technologies, a fertile innovation environment relies on a constant inflow of knowledge from other places (Fey and Birkinshaw, 2005). Most end products embody an increasingly broad set of technologies that require highly specialized capabilities to develop. The upshot is that firms can no longer hope to do everything in-house (Iansiti, 1997). Even the largest innovationactive organizations cannot rely solely on internal sourcing; they also require knowledge from beyond their boundaries when developing innovations (Chesbrough and Crowther, 2006; Rigby and Zook, 2002). In addition to doing internal R\&D, firms typically tap knowledge sources external to the firm through technological consultants, R\&D outsourcing, cooperative agreements, or the hiring of qualified researchers with relevant knowledge (Arora and Gambardella, 1990; Bessant and Rush, 1995; Cockburn and Henderson, 1998; Veugelers and Cassiman, 1999).

Rigby and Zook (2002) have argued for the benefits of opening the innovation process to external knowledge flows. Their case studies show that the ability to combine internal and external information inputs is a critical new source of competitive advantage in some of the fastest growing and most profitable industries. The suggestion is that external inputs can increase the productivity of in-house activities (Cassiman and Veugelers, 2006). The role of external sources - especially alliances - has been shown to be vital for the achievement of innovation outputs in HT firms (de Man and Duysters, 2005; Ku et al., 2007). The need to go beyond internal R\&D activities to look for external sources of innovation, however, is not limited to firms in HT industries. Chesbrough and Crowther (2006) make this point when they suggest that 'open innovation' concepts are finding application in firms operating outside HT industries.

A growing number of studies reveal that diffusing knowledge quickly among industries and firms is a way of achieving and improving innovation performance (Robertson and Patel, 2007). This diffusion of knowledge is sometimes in the shape of equipment, but at others may be more intangible, examples being scientific discoveries, understanding the state of technology, or know-how on adapting technologies developed by others. An important and indirect source of technological opportunity, then, is often located outside the industry in question, typically arriving from a more technology-intensive industry via the utilization of new components, machinery and equipment, or materials (Palmberg, 2004). LMT firms also frequently use high-tech knowledge in original and informal ways (Garibaldo and Jacobson, 2005). Their development tasks are characterized by design, product and process adaptation, and problem solving in collaboration with customers (Hansen and Serin, 1997).

At this point, it is important to ask whether the distinct modes of organization for external sources have a differentiated impact on firm innovativeness. Differences exist between the various contracting mechanisms (such as contracted R\&D, purchase of consulting services and hiring of employees), along with hybrid forms of collaboration (from strong modes of inter-organizational gover-

\footnotetext{
addition, other new skills such as the operating of computer-controlled machines are increasingly required (Schmierl and Köhler, 2005).

${ }^{4}$ He does not distinguish between LMT and HT industries, and focuses only on small enterprises.
}

nance such as joint ventures to weaker modes such as non-equity alliances).

Contracting mechanisms refer to the acquisitions of knowledge on a market basis (Granstrand et al., 1992; Haour, 1992; Mangematin and Nesta, 1999; Ulset, 1996), what could be called 'the buy decision'. A firm can obtain new technology embodied in an asset that is acquired, such as new personnel, parts of other firms or equipment. But new technology can also be obtained disembodied, for example by outsourcing the technology from an R\&D contractor or consulting agency (Veugelers and Cassiman, 1999, p. 66). This paper focuses on three of the possible technology acquisition options: contracted R\&D; the purchase of technological consulting services; and the hiring of personnel.

Although transaction cost theory suggests that the acquisition of external R\&D may substitute for internal R\&D investment (Pisano, 1990; Williamson, 1985), both anecdotal evidence and rigorous empirical research suggest that in-house R\&D and external know-how are complementary (Cassiman and Veugelers, 2006; Cockburn and Henderson, 1998). In addition to conducting internal $R \& D$ activities, firms can reinforce their technological competences by contracting R\&D and other external knowledge, and then communicating, diffusing and assimilating it into their organizations (Prahalad and Hamel, 1990). Internal R\&D, though, is needed to lead and support the external sourcing effort (Chatterji, 1996). Cohen and Levinthal (1990) emphasize that internal R\&D capabilities make it possible to absorb external knowledge effectively.

Technological consultants are another possible source of external knowledge (Creplet et al., 2001; Huber, 1991). Smallbone et al. (1993) point out their relevance for firms that need to develop a new product but that are too small to invest in $R \& D$ in-house, especially in mature industries. Consultants often interact with numerous firms across a variety of industries and therefore may transfer tacit knowledge that has been developed through this ongoing experience of learning, integrating and sharing knowledge (Bierly and Daly, 2007). Bessant and Rush (1995) also highlight the role of consultants in the process of technology transfer. In this way, people are an important conduit of interfirm knowledge transfer (Malecki, 1991). In fact, hiring employees can serve as a mechanism for the acquisition of externally developed knowledge (Teece, 1982; Winter, 1987). Song et al. (2001) empirically test this idea and show that learning-by-hiring can be employed to access and build on external knowledge. Following similar lines of reasoning, Rao and Drazin (2002) show that human mobility enables firms to develop product innovations. Bearing in mind that LMT industries are largely recipients of technology generated in HT industries, it seems likely that LMT firms could take advantage of technological consultants and hiring skilled and knowledgeable employees.

On the other hand, the current surge in collaborations is another reflection of the fact that technological innovations are less and less the output of an individual firm's isolated efforts (Drejer and Jørgensen, 2006; Fischer and Varga, 2002), which has been particularly highlighted in HT industries (Park et al., 2002; Stuart, 1998). Several recent studies have shown the positive impact of technological collaboration on firms' technological activities and performance (e.g. Belderbos et al., 2004; Faems et al., 2005; Hoang and Rothaermel, 2005; Miotti and Sachwald, 2003; Nieto and Santamaria, 2007).

Firms have several alternative ways of organizing their alliance activities (Powell et al., 1996), ranging from technological joint ventures to close-to-the-market arrangements such as non-equity alliances. Technological joint ventures are legal entities in which equity ownership is shared between firms that pool capabilities in order to develop innovation activities in common (Oxley, 1997). In 
non-equity alliances, on the other hand, there is no such shared ownership between firms; this type of collaboration is characterized by a smaller degree of organizational and hierarchical control than in joint ventures. The stronger links between partners in equity joint ventures relieve them of the need to completely specify their rights and obligations and result in better coordination of activities and greater efficiency when responding to unforeseen contingencies (Sampson, 2004, 2007). Equity participation helps protect the interests of firms that must make transaction-specific investments as it allows them to safeguard the ownership of the results and reduce the risk of spillovers better than bilateral contracts would. Non-equity alliances, meanwhile, feature more decentralized decision-making. They make it possible to make faster routine decisions, but are inefficient when coordination is needed or when certain guarantees are required to share information between partners.

In summary, external sources of innovation are critical to a firm's innovation success. Moreover, the choice of other innovation activities beyond formal R\&D is important for the innovation process of LMT firms. Our objective from here on is to analyse these two dimensions empirically. The influence of different non-R\&D activities - design, use and adaptation of machinery, and training together with that of formal R\&D activities on innovation will be analysed. The paper also explores the role played by different external sources of innovation, together with internal R\&D activities, on these innovation outputs.

\section{Methodology}

\subsection{Sample and data}

The database used for our empirical analysis is the Spanish Business Strategies Survey (SBSS). This is an annual firm-level panel of data compiled by the Spanish Ministry of Industry and the Public Enterprise Foundation; it has been used by many other researchers to study innovation (Beneito, 2006; Cuervo-Cazurra and Un, 2007; Huergo, 2006; among others). The SBSS contains an interesting and wide set of variables on Spanish firms operating in all manufacturing industries of the classification NACE-Rev.1.

As noted, the SBSS is not specifically designed to analyse technological activities. It does not restrict its focus to innovative firms and firms' R\&D activities, but offers a more complete picture. These features allow us to go far beyond formal R\&D activities, by considering other innovation activities, alternative sources to internal $R \& D$, and some characteristics of product and factor markets as determinants of innovation. In addition, the SBSS offers other advantages over standard data bases that typically have a very high percentage of firms that perform R\&D activities, which could give rise to biased results (Bayona et al., 2001; Cassiman and Veugelers, 2002; Tether, 2002). The fact that the SBSS does not suffer from this sample bias makes it particularly suitable for capturing the innovative behavior of firms in LMT industries.

The sample is representative of the population of Spanish manufacturing firms. Firms with between 10 and 200 employees are selected through a random stratified sample (according to firm size and industry classification), and firms with more than 200 are surveyed on a census base (Fariñas and Jaumandreu, 2000; Huergo, 2006). Although the SBSS has been compiled since 1990, the 1998 survey was the first to provide information on different innovation activities and external sources of innovation. Consequently, our empirical analysis is based on the balanced sample of firms with information available for the complete period from 1998 to 2002. Our final sample contains 6500 observations from 1300 firms that have remained in the survey during the whole 5-year period.

\subsection{Variables and measures}

\subsubsection{Dependent variables: innovation outputs}

The dependent variables are relative to firm innovation performance in a specific period $t$. In order to capture the different innovation outputs, along with the distinct levels of complexity, three separate measures were used: product innovation, process innovation and the propensity to patent.

Product innovation was assumed to have taken place when the firm declared it had introduced completely new products or products with important modifications, products with new functions resulting from innovation, or had made changes to the design, presentation, materials or composition of the product. Product innovation is a dichotomous variable that takes a value $=1$ when product innovation has occurred; otherwise 0 .

Process innovation was assumed to have happened when the firm indicated it had introduced some significant modification in the production process. This modification may involve the introduction of new machines or new methods of organization, or the introduction of both. Process innovation is also a dichotomous variable.

Lastly, propensity to patent is an effective way of capturing the achievement of more significant and complex innovations. In fact, the requirements to register a patent are usually more stringent than for other innovations (Beneito, 2006). Patent is a dichotomous variable that takes a value $=1$ when the firm stated it had registered at least one patent; otherwise its value is 0 .

\subsubsection{Independent variables related to innovation activities}

The first objective of this paper is to understand the role of other innovation activities beyond formal R\&D in LMT industries. To do this, a wide selection of potential inputs to firms' innovation processes was considered. Thus, along with the decision to perform formal R\&D (internal and/or external), the activities of design, use of advanced manufacturing technology and training were included. The decisions to perform and/or contract each of these activities were measured via dichotomous variables. To avoid problems of simultaneity with the innovation generation process, all these innovation activities were lagged one period.

Formal RED captures the decision to perform formal expenditures on R\&D activities (in-house and/or contracted). It is a dichotomous variable.

Apart from formal measures of $R \& D$ activities, the database includes qualitative data on other innovation activities. It was possible to construct, therefore, dichotomous variables that measure:

- the use of machinery and advanced technology such as automatic machines, robots, CAD/CAM, or some combination of these procedures (Use of AMT);

- the performance and/or contracting of design activities (Design); and

- the performance and/or contracting of training activities (Training).

\subsubsection{Independent variables related to sources of innovation}

The second objective of this paper is to analyse the importance of different sources of innovation beyond internal ones in LMT firms. Along with the decision to perform internal $R \& D$, the fact that the innovation process of firms may benefit from external knowledge flows was taken into account. Thus, decisions to turn to market mechanisms (such as external R\&D, technological consultants or the hiring of qualified researchers), as well as decisions to use hybrid forms of collaboration (non-equity alliances and joint ventures) were analysed. As was the case with innovation activities, 
the different sources of innovation were measured via dichotomous variables that were lagged one period.

Internal $R E D$ captures the decision to perform internal $R \& D$ activities, as a dichotomous variable.

The database also includes data on the external sources that a firm accessed through contracting or market mechanisms. This enables us to identify if a firm:

- decided to contract R\&D external activities (External RED);

- turned to a technological consultant (Consultant); and

- had recently hired engineers, personnel with business experience in R\&D and/or personnel with experience in public systems R\&D (Hiring personnel).

A distinction between the use of two hybrid mechanisms to gain access to external sources of innovation was also made:

- technological collaborations formalized as legal entities in which equity ownership is shared between firms that pool their capabilities (Joint Venture); and

- technological collaborations where there is no shared equity ownership between firms, with a smaller degree of organizational control and greater flexibility (Non-equity alliance).

\subsubsection{Environmental factors}

In addition to the sub-division between LMT and HT industries, we believe that environmental factors are highly important when it comes to understanding the relationship between technological choices and innovation outputs. Indeed, previous studies (Cohen, 1995; Kamien and Schwartz, 1982) have pointed out that demand and market conditions are critical factors in explaining innovation performance. To measure these conditions, different variables related to product and factor market characteristics were employed.

One of the market characteristics analysed was concentration of competitors (Competitors). The concentration of competitors determines the dynamism of the market the firm is operating in and the consequent greater or lesser need to undertake innovation activities (Schumpeter, 1942). It is measured as the percentage of the market that is controlled by the four largest competitors (Kumar and Saqib, 1996). Product and factor market characteristics were also included by considering client and supplier pressures (CuervoCazurra and Un, 2007). Client pressure is measured in terms of the concentration of clients; this is calculated as the percentage of sales to the firm's three largest clients (Client pressure). Similarly, supplier pressure is measured in terms of concentration of suppliers, in this case calculated as the percentage of total purchases from the three main suppliers (Supplier pressure). Lastly, we follow Huergo (2006) in including a variable to measure growth of market demand. This is a dichotomous variable that takes a value $=1$ when the firm stated that its main market was expanding (Expansion).

\subsubsection{Firm-specific characteristics}

Controls for firm-specific characteristics such as size, age and diversification were included. A classical control such as size is measured as the natural logarithm of the number of employees (Size). The age of the firm (Age) is a variable commonly used to measure firm experience and learning in empirical studies of innovation (Kumar and Saqib, 1996). It is measured as the number of years since a firm was founded. Lastly, in line with Henderson and Cockburn (1996) and Helfat (1997), we consider that a diversified firm is better prepared to develop new technological capabilities and re-use them in new activities (i.e. process innovations). Diversification (Diversification) was controlled for with a dichotomous variable that takes a value $=1$ if the firm's main product represents less than $50 \%$ of sales at the three-digit NACE level.

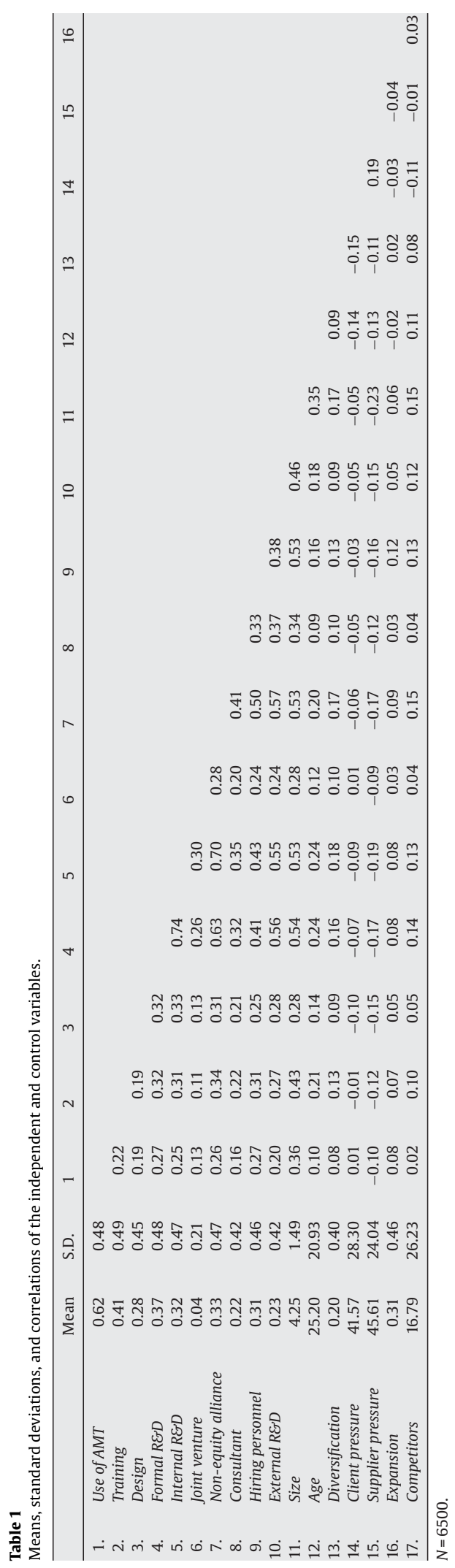


The descriptive statistics and correlations of the independent and control variables are reported in Table 1.

\subsection{Method of analysis}

Given the binary character of the dependent variables and the panel structure of the data, the specification has been estimated assuming a random effects probit model. Two types of models were estimated for each of the three innovation outputs proposed (product innovation, process innovation and patent). The first type, which controlled for market characteristics and firm specificities, analysed the impact of different innovation activities beyond formal R\&D on innovation outputs (Table 3 ). The second type, with the same controls, was used to explore the influence of distinct external sources beyond internal $R \& D$ on these same innovation outputs (Table 4).

The above models were estimated separately for LMT and HT industries in order to attempt to understand the determinants of innovation outputs for LMT industries and to extract some specificities for HT industries. ${ }^{5}$ The OECD's (2005) classification of manufacturing industries based on technology was used to form two groups: LMT and HT. LMT includes firms in low-technology industries (textiles, food products, tobacco, wood, paper products, among others) and in medium-low technology industries (rubber and plastic products, coke, refined petroleum products, other non-metallic mineral products, basic metals, among others). HT includes firms in high-technology industries (aircraft and spacecraft, pharmaceuticals, office machinery, radio, TV and computing machinery, medical, precision and optical instruments) and medium-high technology industries (electrical machinery, motor vehicles, chemicals excluding pharmaceuticals, railroad and transport equipment, machinery and equipment, among others).

\section{Empirical results}

\subsection{A descriptive analysis of innovation behavior}

In order to offer an overview of the innovation behavior of firms in LMT and HT industries, Table 2 summarizes the mean differences about innovation outputs, activities and sources of innovation.

A preliminary consideration of the results indicates that the percentage of firms performing innovation activities is higher in HT than in LMT industries. As would be expected, this finding holds true for the three measures of innovation output: product innovation, process innovation and propensity to patent. On average, the innovation activities performed in the HT and LMT industries also differ. While all of the differences are statistically significant, the most obvious and predictable is in formal $R \& D$ activities. Analysing the mean differences relative to sources of innovation gives us a clear picture of innovation in LMT firms. As can be observed, the mean percentage of LMT firms that turn to internal or external sources of innovation is always significantly lower than that of HT firms.

These findings simply corroborate what was expected in terms of the lower likelihood of LMT firms to perform innovation activities and achieve innovation outputs, and the fact that they look to fewer sources of innovation. Our objective, however, goes beyond this basic comparison. We also intend to explore the potential impact

\footnotetext{
5 The issue of comparing coefficients across groups when using logit or probit models is a controversial question. However, if the model is estimated separately for each group, it is possible - at a minimum - to compare the statistical significance of coefficients across groups (Hoetker, 2007).
}

Table 2

Innovative behavior in LMT and HT industries.

\begin{tabular}{lrcc}
\hline & LMT & HT & Difference $^{\mathrm{a}}$ \\
\hline $\begin{array}{l}\text { Innovation outputs } \\
\quad \text { Product innovation }\end{array}$ & 20.69 & 34.11 & $-13.41^{* * *}$ \\
$\begin{array}{l}\text { Process innovation } \\
\text { Patent }\end{array}$ & 32.05 & 41.77 & $-9.71^{* * *}$ \\
Innovation activities & 5.19 & 10.88 & $-5.68^{* * *}$ \\
$\quad$ Formal RED & & & \\
Use of AMT & 28.62 & 58.38 & $-29.76^{* * *}$ \\
Training & 57.86 & 74.58 & $-16.72^{* * *}$ \\
Design & 35.53 & 54.65 & $-19.12^{* * *}$ \\
Sources of innovation & 25.59 & 37.08 & $-11.49^{* * *}$ \\
$\quad$ Internal RED & & & \\
Joint venture & 24.08 & 53.38 & $-29.30^{* * * *}$ \\
$\quad$ Non-equity alliance & 2.37 & 10.16 & $-7.7^{* * *}$ \\
Consultant & 21.68 & 49.32 & $-27.55^{* * *}$ \\
$\quad$ Hiring personnel & 20.19 & 28.59 & $-8.39^{* * * *}$ \\
External RED & 21.68 & 49.32 & $-27.64^{* * *}$ \\
\hline
\end{tabular}

a Student's $t$-test on the difference between means.

${ }^{* * *}$ Denote samples that are significantly different at the 0.01 level.

of different activities and sources of innovation on the innovation outputs of LMT and HT firms.

\subsection{Impact of innovation activities in LMT industries}

The models displayed in Table 3 examine the impact of different innovation activities on the three measures of innovation performance. The reported coefficients are the estimated marginal effects from our probit models and are computed at the means of the independent variables. The coefficient shows how much the probability of a firm's innovating grows with an increase in that independent variable, while holding the other independent variables constant. The estimations were performed for the two sub-samples: LMT and HT firms. In addition to innovation activities, we controlled for firm specificities and market characteristics for each estimation.

This analysis makes it possible to analyse the importance of other activities beyond formal R\&D for the achievement of innovation outputs in LMT firms. Together with formal R\&D activities, the activities of design (Design) and training (Training), and the use of advanced machinery (Use of AMT) stand out as critical factors in the generation of product and process innovations in LMT firms. Propensity to patent, however, is only explained by formal R\&D activities and design activities. These findings reveal the great importance that design and training activities and the use of advanced machinery have for the innovation process in LMT firms.

In HT firms, formal R\&D activities occupy center stage in the innovation process (regardless of the output indicator analysed). Only design activities (together with advanced machinery for process innovations) appear as a significant complementary factor to R\&D activities. This indicates, however, that even in HT firms other activities beyond formal $R \& D$ are important for the achievement of innovation outputs.

For firm specificities, the highly significant and positive effect of firm size (Size) on all measures of innovation outputs is as expected. Age (Age) has a significant and negative impact on the achievement of process innovations in LMT firms; this may have to do with the organizational inertia that grows with time. This finding seems to square with previous research on manufacturing firms (Huergo and Jamandreu, 2004; Huergo, 2006), though these studies did not focus on the distinction between LMT and HT firms. Lastly, diversification (Diversification) exercises a significant and positive effect on the generation of process innovations in both LMT and HT firms. This result is in line with the view that it may be easier for a diver- 
Table 3

Marginal effects from probit analysis: innovation activities.

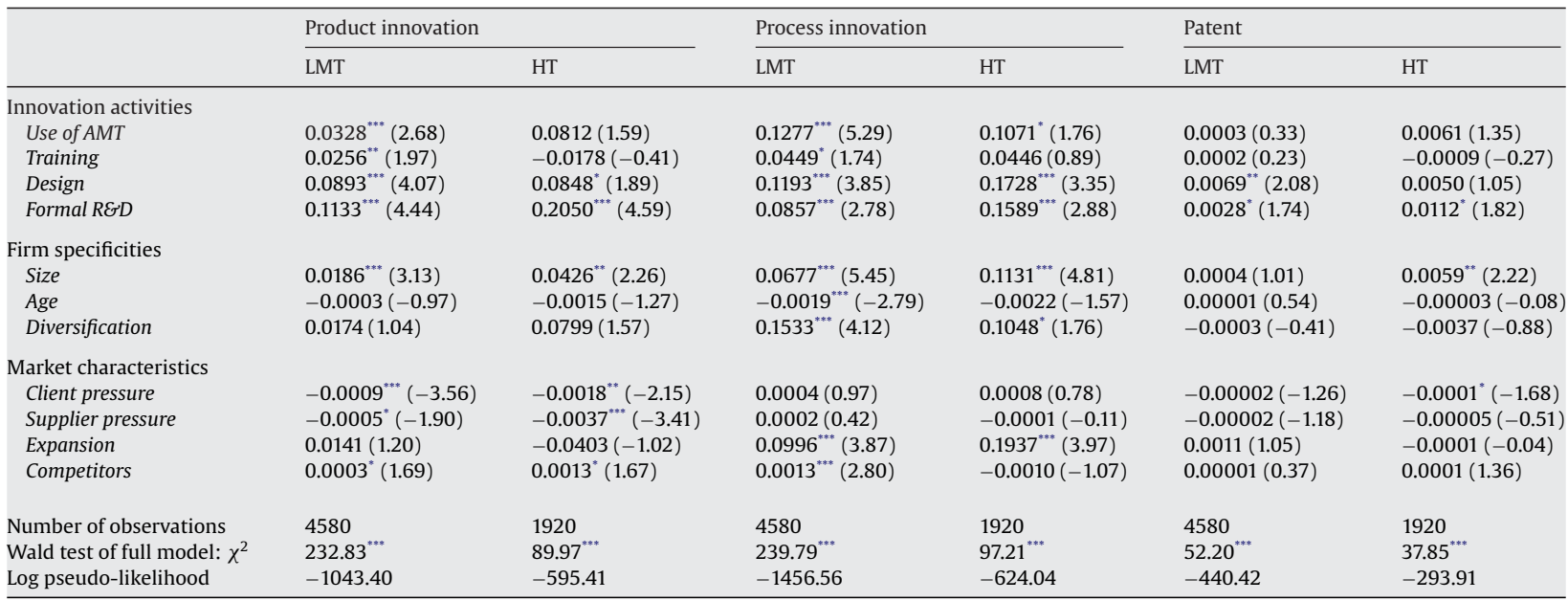

Estimated marginal effects from probit analyses (computed at the mean values of the independent variables) are shown. $t$-Values are in parentheses. Wald test and log pseudo-likelihood from probit models are reported. Year dummies are included in the models.

${ }^{*} p<0.10$.

${ }^{* *} p<0.05$.

*** $p<0.01$.

sified firm to develop and adapt new technologies to improve its activities and processes (Helfat, 1997; Henderson and Cockburn, 1996).

Several interesting findings emerge regarding market characteristics. Environmental factors are found to be extremely important when it comes to explaining product and process innovations, especially in LMT firms. Growth of demand (Expansion) and pressure from main competitors (Competitors) exert a significant and positive effect on the achievement of innovation outputs, particularly on process innovations. Pressure from main clients (Client pressure) and suppliers (Supplier pressure), however, clearly hinder the generation of product innovations in both LMT and HT firms. These results can be interpreted as a sign of rigidity in the innovation capacity of firms that are highly dependent on a small number of clients and/or suppliers.

\subsection{Sources of innovation in LMT industries}

The models displayed in Table 4 examine the role that different sources of innovation play in the achievement of the three innova-

Table 4

Marginal effects from probit analysis: sources of innovation.

\begin{tabular}{|c|c|c|c|c|c|c|}
\hline & \multicolumn{2}{|l|}{ Product innovation } & \multicolumn{2}{|l|}{ Process innovation } & \multicolumn{2}{|l|}{ Patent } \\
\hline & LMT & HT & LMT & HT & LMT & HT \\
\hline \multicolumn{7}{|l|}{ Sources of innovation } \\
\hline Internal RED & $0.1017^{* * *}(3.93)$ & $0.2142^{* * *}(4.40)$ & $0.1059^{* * *}(3.01)$ & $0.0296(0.50)$ & $0.0046^{*}(1.77)$ & $0.0158^{* *}(2.13)$ \\
\hline Joint Venture & $-0.0180(-0.90)$ & $0.0046(0.08)$ & $0.0506(0.69)$ & $0.0772(1.10)$ & $0.0143^{*}(1.75)$ & $0.0147^{*}(1.78)$ \\
\hline Non-equity alliance & $0.0618^{* * *}(2.96)$ & $0.1427^{* * *}(2.95)$ & $0.0065(0.21)$ & $0.0975^{\circ}(1.69)$ & $0.0010(0.63)$ & $-0.0010(-0.24)$ \\
\hline Consultant & $0.0234^{*}(1.68)$ & $0.0556(1.38)$ & $0.1241^{* * *}(4.07)$ & $0.0787^{*}(1.78)$ & $-0.0003(-0.30)$ & $0.0006(0.22)$ \\
\hline Hiring personnel & $0.0020(0.17)$ & $-0.0110(-0.29)$ & $0.0420^{*}(1.72)$ & $0.0581(1.32)$ & $0.0005(0.45)$ & $0.0002(0.09)$ \\
\hline External RED & $0.0050(0.34)$ & $-0.0218(-0.54)$ & $0.0647^{*}(1.87)$ & $0.0622(1.25)$ & $0.0014(0.82)$ & $0.0118^{*}(1.81)$ \\
\hline \multicolumn{7}{|l|}{ Firm specificities } \\
\hline Size & $0.0244^{* * *}(3.99)$ & $0.0410^{* *}(2.33)$ & $0.0656^{* * *}(5.44)$ & $0.1148^{* * *}(5.32)$ & $0.0006(1.19)$ & $0.0031^{*}(1.87)$ \\
\hline Age & $-0.0001(-0.51)$ & $-0.0008(-0.74)$ & $-0.0017^{* * *}(-2.59)$ & $-0.0017(-1.28)$ & $0.00001(0.18)$ & $0.00001(0.06)$ \\
\hline Diversification & $0.0173(1.05)$ & $0.0604(1.33)$ & $0.1311^{* * *}(3.77)$ & $0.0848(1.67)$ & $-0.0013(-1.18)$ & $-0.0015(-0.47)$ \\
\hline \multicolumn{7}{|l|}{ Market characteristics } \\
\hline Client pressure & $-0.0008^{* * *}(-3.50)$ & $-0.0003(-0.39)$ & $0.0003(0.81)$ & $0.0008(0.96)$ & $-0.00004^{*}(-1.69)$ & $-0.00009(-1.31)$ \\
\hline Supplier pressure & $-0.0005^{* *}(-2.06)$ & $-0.0023^{* *}(-2.41)$ & $0.00004(0.08)$ & $-0.0007(-0.69)$ & $-0.00005^{*}(-1.71)$ & $0.00003(0.42)$ \\
\hline Expansion & $0.0150(1.33)$ & $-0.0129(-0.39)$ & $0.0915^{* * *}(3.96)$ & $0.1619^{* * *}(3.90)$ & $0.0007(0.65)$ & $0.0028(0.88)$ \\
\hline Competitors & $0.0005^{* *}(2.35)$ & $0.0011^{*}(1.71)$ & $0.0012^{* * *}(2.87)$ & $-0.0003(-0.40)$ & $0.00002(0.87)$ & $0.00007(1.21)$ \\
\hline Number of observations & 4580 & 1920 & 4580 & 1920 & 4580 & 1920 \\
\hline Wald test of full model: $\chi^{2}$ & $255.87^{* * *}$ & $119.33^{* * *}$ & $258.13^{* * *}$ & $122.56^{* * *}$ & $58.24^{* * *}$ & $68.05^{* * *}$ \\
\hline Log pseudo-likelihood & -1314.75 & -739.42 & -1802.74 & -800.07 & -564.85 & -351.51 \\
\hline
\end{tabular}

Estimated marginal effects from probit analyses (computed at the mean values of the independent variables) are shown. $t$-Values are in parentheses. Wald test and log pseudo-likelihood from probit models are reported. Year dummies are included in the models.

${ }^{*} p<0.10$.

${ }^{* *} p<0.05$.

*** $p<0.01$. 
tion outputs previously analysed. The reported coefficients are also the estimated marginal effects from our probit models. Our objective is to measure how market mechanisms and hybrid forms of collaboration, along with internal R\&D activities, each contribute to the innovation process of LMT firms. As before, to do this the estimations were performed for the two sub-samples: LMT and HT firms. Once again, firm specificities and market characteristics for each estimation were controlled for.

The estimations uncover two interesting findings on the role exercised by sources of innovation. First, in-house R\&D is shown to be highly important for all types of innovation output in LMT and HT industries. Second, there are clear differences between the importance of the various external sources depending on the measure of performance and the type of industry analysed.

Hiring technical consultants (Consultant) is seen to be very relevant for the achievement of product and process innovations in LMT firms. For HT firms, however, this is only significant for the achievement of process innovations. Hiring specialized personnel (Hiring personnel) is significant for the generation of process innovations in LMT firms, but is irrelevant in HT firms. Contracting R\&D (External RED) exerts a significant and positive impact on process innovations in LMT firms, while in HT firms it is important for the production of patents.

Great differences in the effect of hybrid forms of collaboration between LMT and HT firms are not observed. Interesting interpretations, however, can be extracted on the differential impact they have on the various measures of innovation outputs. Non-equity alliances have a very marked influence on the achievement of product innovations, while joint ventures are critical for the production of patents. This last finding is highly important as it demonstrates how the greater control and coordination offered by joint ventures is an advantage for achieving more complex innovations where the risk of spillovers must be controlled.

Lastly, the results of the controls on firm specificities and market characteristics are very similar to those observed in the models analysing the impact of innovation activities. We interpret this as a sign of the robustness of the models.

\section{Discussion and conclusions}

The literature on innovation and technological change has overstated the role of R\&D activities as innovation determinants, and this has resulted in disproportionate importance being attributed to a small number of relatively research-intensive industries. The pre-eminence of the linear model of innovation along with the configuration of R\&D statistics may explain the misunderstanding of the innovation process in LMT industries (Hirsch-Kreinsen et al., 2005,2006 ). The main objective of this paper, then, is to deepen our understanding of the innovation behavior and performance of LMT firms. To achieve this goal, this study has performed an empirical analysis of how different activities beyond formal R\&D and different sources of innovation beyond firms' boundaries impact on a selection of indicators of innovation outputs.

Our results reveal some key aspects that help bridge the cognitive gap between the innovation process in LMT and HT industries. In particular, our empirical evidence strongly supports the view that non-R\&D activities are crucial to understanding the innovation process of any firm. The impact of these activities beyond formal R\&D is especially important in LMT industries, particularly for the achievement of product innovations. Specifically, this study has shown that design, the use of advanced machinery and training are decisive factors for innovation outputs.

Above all others, design emerges as a pivotal problem-solving activity that is a critical driver of innovation in LMT firms. It is decisive for all of the indicators of output analysed. This is not surprising given that design covers many activities ranging from ergonomics, ease of manufacture, efficient use of materials and user friendliness to the frequent incorporation of innovative technologies, components or materials. As Walsh (1996) points out, design plays a highly integrative role among inventions, markets and production processes.

The use of advanced machinery is also seen to be important in LMT industries for both product and process innovations. New technologies create new opportunities for LMT industries to enhance their innovation and economic performance (von Tunzelmann and Acha, 2005). In line with this, we observe that LMT firms that take advantage of these opportunities are more innovative. Laestadius (2005) provides one plausible explanation for this by stating that the adoption and use of advanced machinery make the old competences obsolete and help to develop new ones, thereby opening the firm to new possibilities. In fact, in LMT industries the learning process is commonly performed in practical and pragmatic ways by doing and using (von Tunzelmann and Acha, 2005).

Our results for training activities indicate that they are also a key factor for the achievement of innovations in LMT industries. Some authors argue that LMT industries increasingly require hybrid qualifications that are not provided by the market and need to be fulfilled by training (Schmierl and Köhler, 2005). In addition, the need for training is by no means limited to R\&D staff (Leiponen, 2005).

We also observe some interesting features when different sources of innovation are considered. Although internal R\&D emerges as a fundamental source of innovation, our empirical evidence confirms the importance of other sources based on external contracting and collaboration, as the previous literature has pointed out (Arora and Gambardella, 1990; Fey and Birkinshaw, 2005; Veugelers and Cassiman, 1999; among many others). The greatest differences between LMT and HT firms are observed in the context of process innovations. The use of consultants, the hiring of personnel and external R\&D are particularly significant external sources of innovation in LMT industries. In the case of product innovations, consultants are a significant factor for LMT firms, but not for HT firms.

Focusing on the collaboration-based alternatives, our results reveal that non-equity alliances - characterized by more decentralized decision-making - are important for LMT and HT firms, especially for product innovations. They have no impact, however, when more coordination and control is required, as is the case with patents. Joint ventures, meanwhile, are more effective when the firm is looking to achieve patentable results. These findings support Sampson's (2007) arguments that joint ventures produce a stronger link and greater coordination between partners.

We are able to conclude, then, that LMT firms have alternative innovation sources beyond internal R\&D that may be highly useful for achieving different innovation outputs. The key question for the firm to answer, depending on the output sought, is whether to go for a market-based (e.g. external R\&D or consultants) or an organization-based arrangement (e.g. non-equity alliances or joint ventures).

Our analysis also allows us to conclude that innovation outputs in LMT industries are highly dependent on product and factor market conditions. In LMT industries, the economic opportunities can be just as important as the technological opportunities (von Tunzelmann and Acha, 2005). One of the results observed is that being in a growing market induces process innovations. In addition, we observe that access to a limited number of clients and suppliers clearly limits a firm's outlook and has a negative effect on innovation outputs. As a firm's knowledge base and technological capabilities are by definition limited, this finding 
may be interpreted as evidence that limiting a firm's outlook affects the penetration of technologies and innovation behavior (Smith, 2000).

The empirical analysis clearly shows that innovation can and does take place in industries and firms with relatively low or even no R\&D. If innovation is understood in the broadest sense as "the processes by which firms master and get into practice product designs and manufacturing processes that are new to them, whether or not they are new to the universe, or even to the nation" (Nelson and Rosenberg, 1993, p. 4), then it is clear that many firms without formal R\&D are innovative. As we have shown, $R \& D$ is only one of the innovation determinants. Innovation also depends on other activities and sources, along with environmental and marketrelated factors. We consider, therefore, that studies of innovation have been overly concerned with the role of R\&D activities, while one of the main requirements to understand the innovation process is to take a holistic view of the firm.

It is certainly true that R\&D is a way of generating highly relevant conditions for inputs into innovation processes. In fact, analysing the determinants of innovation outputs with a greater scientific component (i.e. patents) reveals that $R \& D$ activities are critical. But it is also evident that innovation is by no means always based on scientific research (Dosi, 1988; Gibbons et al., 1994). For this reason we follow von Tunzelmann and Acha (2005) in believing that policy has been too focused on purported gaps in HT industries. This has distracted the attention of policy-makers (and also of academics) from making greater efforts to foster and sustain development in LMT industries, which some countries might find more viable.

The more visible nature of radical innovations has been largely responsible for shifting policy-making in favor of HT industries. Most firms, however, do not make radical innovations (only very few firms make them and they are clustered in certain industries), but all can and should make incremental innovations and adopt new products and processes first made by others (Freeman, 1994). Furthermore, the economic importance of incremental innovation is extremely high despite being understated in the literature (Walsh, 1996). Products and processes are usually changed considerably during the diffusion and adoption process and gains in productivity are very high in this stage.

From the point of view of innovation policy, the recommendations are straightforward: Innovation policy should not be so biased to formal and internal R\&D activities. It should recognize the great importance for innovation of other related activities and sources, especially in LMT industries. As recognized by Mowery and Rosenberg (1989), improving the adoption and commercialization of new technologies requires initiatives that go well beyond the boundaries of conventionally defined science and technology policy. Teubal (1997) states that innovation policy should be horizontal, oriented to all industries in the economy, and that there should be a framework to facilitate innovation activities by firms. Such a policy should act as a catalyst, stimulating firms to learn how to perform technological activities and working to diffuse new routines, especially in search and learning processes.

This study leads naturally to further research. Once the importance of other innovation activities beyond formal R\&D has been shown, the next step will be to explore in depth the innovation process of firms that do not perform R\&D activities. This would allow us to cast even more light on the capabilities and innovation outputs of LMT industries.

Lastly, it is important to note the generalizability of these findings. Although our data are limited to Spain, previous studies have highlighted why this is a good country for study and pointed out some interesting characteristics of LMT industries (Álvarez and Molero, 2005). Apart from representing a large percentage of the manufacturing industries, Spanish LMTs have a long track record of improvement and display above average technological performance (Robertson and Patel, 2007), thus enabling them to benefit enormously from the diffusion of knowledge and information inputs from other firms and industries. These results may be generalizable to other European countries whose firms have similar patterns of technological behavior to those of Spanish firms.

\section{Acknowledgements}

We are grateful to the editors of this issue and the anonymous reviewers for helpful comments and suggestions of this work. The authors would like to acknowledge the financial support from projects CCG07-UC3M/HUM-3287 and SEJ2007-67582-C0202/ECON. The usual disclaimer applies.

\section{References}

Álvarez, I., Molero, J., 2005. Technology and the generation of international knowledge spillovers: an application to Spanish manufacturing firms. Research Policy $34,1440-1452$.

Arora, A., Gambardella, A., 1990. Complementarity and external linkages: the strategies of the large firms in biotechnology. Journal of Industrial Economics 38, 361-379.

Bagchi-Sen, S., 2001. Product innovation and competitive advantage in an area of industrial decline: the Niagara region of Canada. Technovation 21, 45-54.

Bayona, C., Garcia-Marco, T., Huerta, E., 2001. Firms' motivations for cooperative R\&D: an empirical analysis of Spanish firms. Research Policy 30, 1289-1307.

Belderbos, R., Carree, M., Diederen, B., Lokshin, B., Veugelers, R., 2004. Heterogeneity in R\&D co-operation strategies. International Journal of Industrial Organization $22,1237-1263$.

Bender, G., Laestadius, S., 2005. Non-science based innovativeness: on capabilities relevant to generate profitable novelty. In: Bender, G., Jacobson, D., Robertson, P.L. (Eds.), Non-Research-Intensive Industries in the Knowledge Economy. Journal for Perspectives on Economic Political and Social Integration, 11 (1-2), $123-170$.

Beneito, P., 2006. The innovative performance of in-house and contracted R\&D in terms of patents and utility models. Research Policy 35, 502-517.

Bessant, J., Rush, H., 1995. Building bridges for innovation: the role of consultants in technology transfer. Research Policy 24, 97-114.

Bierly III, P.E., Daly, P.S., 2007. Sources of external organisational learning in small manufacturing firms. International Journal of Technology Management 38, 45-68.

Cassiman, B., Veugelers, R., 2002. R\&D co-operation and spillovers: some empirical evidence from Belgium. American Economic Review 92 (4), 1169-1185.

Cassiman, B., Veugelers, R., 2006. In search of complementarity in innovation strategy: internal R\&D and external knowledge acquisition. Management Science 52, 62-82.

Chatterji, D., 1996. Accessing external sources of technology. Research Technology Management 39 (2), 48-56.

Chesbrough, H., Crowther, A.K., 2006. Beyond high tech: early adopters of open innovation in other industries. R\&D Management 36 (3), 229-236.

Cockburn, I., Henderson, R., 1998. Absorptive capacity, coauthoring behaviour and the organization of research in drug discovery. Journal of Industrial Economics 46, 157-182.

Cohen, W.M., 1995. Empirical studies of innovative activity. In: Stoneman, P. (Ed.), Handbook of the Economics of Innovation and Technological Change. Blackwell, Oxford, pp. 182-264.

Cohen, W.M., Levinthal, D.A., 1990. Absorptive capacity: a new perspective of learning and innovation. Administrative Science Quarterly 35, 128-152.

Creplet, F., Dupouet, O., Kern, F., Mehmanpazir, B., Munier, F., 2001. Consultants and experts in management consulting firms. Research Policy 30 (9), 1517-1535.

Cuervo-Cazurra, A., Un, C.A., 2007. Regional economic integration and R\&D investment. Research Policy 36, 227-246.

de Jong, J.P.J., Vermeulen, P.A.M., 2006. Determinants of product innovation in small firms: a comparison across industries. International Small Business Journal 24, 587-609.

de Man, A.-P., Duysters, G., 2005. Collaboration and innovation: a review of the effects of mergers, acquisitions and alliances on innovation. Technovation 25 , 1377-1387.

Dosi, G., 1988. The nature of innovative process. In: Dosi, G., Freeman, C., Nelson, R., Silverberg, G., Soete, L. (Eds.), Technical Change and Economic Theory. Frances Pinter, London, pp. 221-238.

Drejer, I., Jørgensen, B.H., 2006. The dynamic creation of knowledge: analysing public-private collaborations. Technovation 25, 83-94. 
Faems, D., Van Looy, B., Debackere, K., 2005. Inter-organizational collaboration and innovation: toward a portfolio approach. Journal of Product Innovation Management 22, 238-250.

Fariñas, J.C., Jaumandreu, J., 2000. Diez años de Encuesta sobre Estrategias Empresariales (ESEE). Economía Industrial 329, 29-42.

Fey, C.F., Birkinshaw, J., 2005. External sources of knowledge, governance mode, and R\&D performance. Journal of Management 31 (4), 597-621.

Fischer, M., Varga, A., 2002. Technological innovation and interfirm cooperation: an exploratory analysis using survey data from manufacturing firms in the metropolitan region of Vienna. International Journal of Technology Management $24,724-742$.

Freel, M.S., 2005. Patterns of innovation and skills in small firms. Technovation 25 $123-134$

Freeman, C., 1994. The economics of technical change. Cambridge Journal of Economics 18, 463-514.

Garibaldo, F., Jacobson, D., 2005. The role of company and social networks in low-tech industry. In: Bender, G., Jacobson, D., Robertson, P.L. (Eds.), Non-ResearchIntensive Industries in the Knowledge Economy. Journal for Perspectives on Economic Political and Social Integration, $11(1-2), 233-270$.

Gibbons, M., Limoges, C., Nowotny, H., Schwartzman, S., Scott, P., Trow, M., 1994 The New Production of Knowledge: The Dynamics of Science and Research in Contemporary societies. Sage Publications, London.

Granstrand, O., Bohlin, E., Oskarsson, C., Sjöberg, N., 1992. External technology acquisition in large multi-technology corporations. R\&D Management 22, 111-133.

Hansen, P., Serin, G., 1997. Will low technology products disappear?: the hidden innovation processes in low technology industries. Technological Forecasting and Social Change 55, 179-191.

Haour, G., 1992. Stretching the knowledge base of the enterprise through contract research. R\&D Management 22, 177-182.

Helfat, C.E., 1997. Know-how and asset complementarity and dynamic capability accumulation: the case of $R \& D$. Strategic Management Journal 18 339-360.

Henderson, R., Cockburn, I., 1996. Scale, scope and spillovers: the determinants of research productivity in drug discovery. Rand Journal of Economics 27, 32-59.

Hirsch-Kreinsen, H. Jacobson, D., Laestadius, S., Smith, K., 2005. Low and medium technology industries in the knowledge economy: the analytical issues. In: Hirsch-Kreinsen, H., Jacobson, D., Laestadius, S. (Eds.), Low-tech Innovation in the Knowledge Economy. Peter Lang, Frankfurt am Main, pp. 11-30.

Hirsch-Kreinsen, H., Jacobson, D., Robertson, P.L., 2006. 'Low-tech' industries: innovativeness and development perspectives-a summary of a European research project. Prometheus 24, 3-21.

Hoang, H., Rothaermel, F., 2005. The effect of general and partner-specific alliance experience on joint $R \& D$ project performance. Academy of Management Journal 48 (2), 332-345.

Hoetker, G., 2007. The use of logit and probit models in strategic management research: critical issues. Strategic Management Journal 28, 331-343.

Hofmann, C., Orr, S., 2005. Advanced manufacturing technology adoption: the German experience. Technovation 25, 711-724.

Huber, G.P., 1991. Organizational learning: the contributing processes and the literatures. Organization Science 2, 88-115.

Huergo, E., Jamandreu, J., 2004. How does probability of innovation change with firm age? Small Business Economics 22, 193-207.

Huergo, E., 2006. The role of technological management as a source of innovation: evidence from Spanish manufacturing firms. Research Policy 35, 1377-1388.

Iansiti, M., 1997. From technological potential to product performance: an empirical analysis. Research Policy 26 (3), 345-365.

Kaloudis, A., Sandven, T., Smith, K., 2005. Structural change, growth and innovation: the roles of medium and low-tech industries, 1980-2002. In: Bender, G. Jacobson, D., Robertson, P.L. (Eds.), Non-Research-Intensive Industries in the Knowledge Economy. Journal for Perspectives on Economic Political and Social Integration, 11 (1-2), 49-73.

Kamien, M., Schwartz, N., 1982. Market Structure and Innovation. Cambridge University Press, Cambridge.

Kleinknecht, A., van Montfort, K., Brouwer, E., 2002. The non-trivial choice between innovation indicators. Economics of Innovation and New Technology 11 (2), 109-121.

Ku, K.-C., Gurumurthy, C.K., Kao, H.-P., 2007. Inter-firm collaboration of joint ventures in IC foundry business. Technovation 27, 296-305.

Kumar, N., Saqib, M., 1996. Firm size, opportunities for adaptation and in-house R\&D activity in developing countries: the case of Indian manufacturing. Research Policy 25 (5), 713-722.

Laestadius, S., 2005. Innovation -On the development of a concept and its relevance in the knowledge economy. In: Hirsch-Kreinsen, H., Jacobson, D., Laestadius, S. (Eds.), Low-Tech Innovation in the Knowledge Economy. Peter Lang, Frankfurt am Main, pp. 99-122.

Laestadius, S., Pedersen, T., Sandven, T., 2005. Towards a new understanding of innovativeness and of innovation based indicators. In: Bender, G., Jacobson, D., Robertson, P.L. (Eds.), Non-Research-Intensive Industries in the Knowledge Economy. Journal for Perspectives on Economic Political and Social Integration, $11(1-2), 75-122$

Leiponen, A., 2005. Skills and innovation. International Journal of Industrial Organization 23, 303-323.

MacPherson, A., Ziolkowski, M., 2005. The role of university-based industria extension services in the business performance of small manufacturing firms: case-study evidence from Western New York. Entrepreneurship \& Regional Development 17, 431-447.

Malecki, E.J., 1991. Technology and Economic Development. John Wiley and Sons, New York.

Mangematin, V., Nesta, L., 1999. What kind of knowledge can a firm absorb? International Journal of Technology Management 18 (3/4), 149-172.

Marsili, O., Salter, A., 2006. The dark matter of innovation: design and innovative performance in Dutch manufacturing. Technology Analysis \& Strategic Management 18 (5), 515-534.

Metcalfe, S., 1988. The diffusion of innovation: an interpretative survey. In: Dosi, G., Freeman, C., Nelson, R., Silverberg, G., Soete, L. (Eds.), Technical Change and Economic Theory. Frances Pinter, London, pp. 560-589.

Miotti, L., Sachwald, F., 2003. Co-operative R\&D: why and with whom?-an integrated framework of analysis. Research Policy 32, 1481-1499.

Mowery, D., Rosenberg, N., 1989. Technology and the Pursuit of Economic Growth Cambridge University Press, Cambridge.

Nelson, R., Rosenberg, 1993. Technical innovation and national systems. In: Nelson, R (Ed.), National Innovation Systems. A Comparative Analysis. New York University Press, New York, pp. 3-21.

Nieto, M.J., Santamaria, L., 2007. The importance of diverse collaborative networks for the novelty of product innovation. Technovation 27, 367-377.

OECD, 2005. Oslo Manual: Guidelines for Collecting and Interpreting Innovation, 3rd ed. OECD Publications, Paris.

Oxley, J.E., 1997. Appropriability hazards and governance in strategic alliances: a transaction cost approach. Journal of Law, Economics \& Organization 13, 387-409.

Park, S.H., Chen, R., Gallagher, S., 2002. Firm resources as moderators of the relationship between market growth and strategic alliances in semiconductor start-ups. Academy of Management Journal 45 (3), 527-545.

Pavitt, K., 1984. Sectoral patterns of technical change: towards a taxonomy and a theory. Research Policy 13, 343-373.

Palmberg, C., 2004. The sources of innovations: looking beyond technological opportunities. Economics of Innovation and New Technology 13 (2), $183-$ 197.

Pedersen, T., 2005. Two types of 'low-tech' sophistication: production techniques, product design and formal competence in Norwegian mechanical engineering. In: Hirsch-Kreinsen, H., Jacobson, D., Laestadius, S. (Eds.), Lowtech Innovation in the Knowledge Economy. Peter Lang, Frankfurt am Main, pp. 253-284.

Pisano, G.P., 1990. The R\&D boundaries of the firm: an empirical analysis. Administrative Science Quarterly 35, 153-176.

Powell, W., Koput, K. Smith-Doerr, L, 1996. Inter-organizational collaboration and the locus of innovation: networks of learning in biotechnology. Administrative Science Quarterly 41, 116-146.

Prahalad, C.K., Hamel, G., 1990. The core competences of the corporation. Harvard Business Review 68 (3), 71-91.

Rao, H., Drazin, R., 2002. Overcoming resource constraints on product innovation by recruiting talent from rivals: a study of the mutual fund industry, 1986-94. Academy of Management Journal 45 (3), 491-507.

Rigby, D., Zook, C., 2002. Open-market innovation. Harvard Business Review 80 (10), $80-89$

Robertson, P.L., Patel, P.R., 2007. New wine in old bottles: technological diffusion in developed economies. Research Policy 36 (5), 708-721.

Rosenberg, N., 1982. Inside the Black Box: Technology and Economics. Cambridge University Press, Cambridge.

Sampson, R.C., 2004. Organizational choice in R\&D alliances: knowledge-based and transaction cost perspectives. Managerial and Decision Economics 25, 421-436.

Sampson, R.C., 2007. R\&D alliances and firm performance: the impact of technological diversity and alliance organization on innovation. Academy of Management Journal 50 (2), 364-386.

Schmierl, K., Köhler, H., 2005. Organisational learning: knowledge management and training in low-tech and medium low-tech companies. In: Bender, G., Jacobson, D., Robertson, P.L. (Eds.), Non-Research-Intensive Industries in the Knowledge Economy. Journal for Perspectives on Economic Political and Social Integration $11(1-2), 171-221$.

Smallbone, D., North, D., Leigh, R., 1993. The use of external assistance by mature SMEs in the UK: some policy implications. Entrepreneurship \& Regional Development 5, 279-295.

Schumpeter, J.A., 1942. Capitalism, Socialism and Democracy. Harper and Row New York.

Smith, K., 2000. Innovation as a systemic phenomenon: rethinking the role of policy. Enterprise \& Innovation Management Studies 1, 73-102.

Sohal, A., Sarros, A., Schroder, R., O'Neill, P., 2006. Adoption framework for advanced manufacturing technologies. International Journal of Production Research 44 (24), 5225-5246.

Song, J., Almeida, P., Wu, G., 2001. Mobility of engineers and cross-border knowledge building: the technological catching-up case of Korean and Taiwanese semiconductor firms. In: Chesbrough, $\mathrm{H}$, Burgelman, $\mathrm{R}$. (Eds.) Research in Technology and Innovation Management. Elsevier, New York pp. 59-84.

Sterlacchini, A, 1999. Do innovative activities matter to small firms in non R\&D intensive industries?: an application to export performance. Research Policy 28, 819-832. 
Stuart, T.E., 1998. Network positions and propensities to collaborate: an investigation of strategic alliance formation in a high-technology industry. Administrative Science Quarterly 43, 668-698.

Teece, D.J., 1982. Towards an economic theory of the multiproduct firm. Journal of Economic Behavior and Organization 3, 39-63.

Tether, B., 2002. Who co-operates for innovation, and why: an empirical analysis. Research Policy 31, 947-967.

Teubal, M., 1997. A catalytic and evolutionary approach to horizontal technology policies (HTPs). Research Policy 25, 1161-1188.

Ulset, S., 1996. R\&D outsourcing and contractual governance: an empirical study of commercial R\&D projects. Journal of Economic Behavior and Organization 30 , 63-82.

Veugelers, R., Cassiman, B., 1999. Make and buy in innovation strategies: evidence from Belgian manufacturing firms. Research Policy 28, 63-80. von Tunzelmann, N., Acha, V., 2005. Innovation in 'low-tech' industries. In: Fagerberg, J., Mowery, D., Nelson, R. (Eds.), The Oxford Handbook of Innovation. Oxford University Press, Oxford, pp. 407-432.

Walsh, V., 1996. Design, innovation and the boundaries of the firm. Research Policy 25, 509-529.

Warner, M., 1996. Innovation and training. In: Dodgson, M., Rothwell, R. (Eds.), The Handbook of Industrial Innovation. Edward Elgar, Cheltenham, pp. 348-354.

Williamson, O.E., 1985. The Economic Institutions of Capitalism: Firms, Markets, Relational Contracting. The Free Press, New York.

Winter, S., 1987. Knowledge and competence as strategic assets. In: Teece, D.J. (Ed.), The Competitive Challenge: Strategies for Industrial Innovation and Renewal Ballinger, Cambridge, MA, pp. 159-184. 